\title{
Changing Pedagogies in Adult Education Teaching and Learning: Heutagogy an Option
}

\author{
Okorie, Christiana Uzoaru (Ph.D) \\ Department of Adult and Non-Formal Education, Faculty of Education, University of Port Harcourt, Nigeria
}

\begin{abstract}
The study investigated the issue of changing pedagogies in teaching and learning of adult education at post graduate level in Nigeria. It was guided by three research objectives and questions. The study built was built heutagogy approach to teaching and learning which is hinged on student-centeredness where student play immediate and on-going role in what they learn, when to learn and how they learn. The study adopted descriptive survey design. Population of the study comprised lecturers in the department of adult education in Universities in South-South Geopolitical Zone of Nigeria. Only lecturers who teaches post graduate students were purposively sampled. The researcher used a structured questionnaire designed with google form to gather data for the study. Data was collected via electronic mailing. Findings shows that lecturers that teaches post graduate students in Adult and Non-Formal Education Departments in Nigeria Universities still engage in pedagogical teaching and learning in their post graduate class; they also agreed that there is need to change pedagogies in teaching and learning due challenges involve in the changes associated with the present knowledge economy. But the lecturer's level of awareness of heutagogy as a teaching and learning approach for $21^{\text {st }}$ century learners is low. The researcher thus recommended that lecturers should avail themselves opportunities of training and re-training in new ways of teaching in the $21^{\text {st }}$ century to meet up with the challenges of present knowledge economy.
\end{abstract}

Keywords: Pedagogies, Teaching and Learning, Adult Education, Andragogy, Heutagogy

\section{INTRODUCTION}

$\mathrm{I}^{\mathrm{n}}$ $\mathrm{n}$ the world we find ourselves today, adults are faced with different challenging issues from global, regional, national and even at local levels. These challenges also call for developing of adults who can survive and strive in the changing global knowledge economy through a lifelong education process. Adult education as lifelong learning is meant to develop and enrich adult with capabilities to effectively and creatively apply skills and competencies to new situations in an ever-changing, complex world, this means that teaching and learning in adult education in the world of today need a change in the pedagogies to a different teaching and learning approach which will produce learners who are well-prepared for the complexities of today's workplace.Knowles (1970), the father of adult education promotion referred andragogy as a learner-focused pedagogical practices which is different from conventional teacher-oriented, test-driven, lecture-based adolescents or children's teaching. He furtherexplained that "andragogy is a self-directed learning in which individuals take the initiative, with or without the help of others, in diagnosing their learning needs, formulating learning goals, identifying human and material resources for learning, choosing and implementing learning strategies, and evaluating learning outcomes". Although Knowles (1970) through andragogy provided many useful approaches for improving educational methodology, mostly adult teaching and learning, andragogy is still associated to a teacher-learner relationship. But since the introduction of andragogy and to the present time, lots have change and continue to change in the world, in every new year, adults are exposedto many changes in which selfdirected type of teaching and learning is no longer filling the gap mostly in terms of capabilities required in present technology world and work place, rapid technological advancement in the world of work today allows employees to interact with a global market, and even take work out on the road. Human resource leaders and facility managers are feeling the brunt of these rapid changes and the vulnerable impact since it has taken over our professional lives.Also, rapid rate of change in society, and the so-called information explosion, suggest that we should now be looking at an educational approach where it is the learner himself who determines what and how learning should take place.

In the University, we encounter undergraduate students who are fresh from secondary school where the teaching is basically pedagogical. This pedagogical approach is a unidirectional transfer of knowledge from teacher to the learner, but as the students are transitioning to adulthood, It become important for teachers to change the pedagogical approach to a self-directed approach (andragogy) to enable the students at this stage to become familiar with their learning and also reflect on their learning. Chacko (2018) observed that "transition from pedagogy to andragogy in teaching and learning in adult education is usually marked by student ability to reflect on their learning experiences. After the undergraduate level, those students that will return back for postgraduate programme are already adult education graduates that are ready to become professional adult educators with different learningneeds. Accordingly, Chacko (2018) pointed out that student at this level:

at this stage of learning, it required the need for a different approach to meet the learning needs and style of the graduatewho are highly autonomous and for whom pedagogical and even andragogical educational methods are no longer an answer to preparing the professionally qualified learners for thriving in the workplace and so a more self-directed 
and self-determined approach is needed where the learner reflects on what is learned and how it is learned and where the educators teach the learners how to teach themselves, this is termed as Heutagogy which is based on humanistic theory, Chacko, 2018, p.279

Heutagogy at this point of teaching and learning of would be professional adult educators, will appropriate to the needs of learners in the workplace in the twenty-first century, particularly in the development of individual capability.

\section{Statement of the Problem}

Teaching and learning at the universities across Nigeria today is mostly based on the pedagogical (teacher centered/teacher directed) approach which is no longer fit for the development of lifelong learners in the present $21^{\text {st }}$ century because $21^{\text {st }}$ century brought about change in human learning and this change has equally affected the education in general. Education today is geared towards unlimited adventure of different learning experiences which allows learners to construct knowledge in their mind as lifelong learners. In order for our graduates of today to be able to construct knowledge and also to be capable lifelong learners, they need to taught in a way that they are agents of their own learning (self-determined). To be able to do this, $21^{\text {st }}$ century teaching and learning required a shift from the pedagogical (teacher centered/teacher directed) learning approach to a more holistic teaching and learning approach called heutagogy (selfdetermined). The need to produce would be professional adult educators who are capable of filling the gaps provided by the challenges of knowledge economy and changes in human learning, which $21^{\text {st }}$ century brought to education presently prompted this study.

\section{Purpose of the Study}

This study is carried out to investigate the issue of changing pedagogies in teaching and learning of adult educationat post graduate level in Nigeria.The objectives of the study are to:

1. Examine the level to which lecturers in the Adult and Non-Formal Education Departments in selected Universities in Nigeria engage in pedagogical teaching and learning at the post graduate class.

2. Find out the opinion of lecturers in Adult and NonFormal Education Departmentsin selected Universities in Nigeria on changing pedagogies in teaching and learning of adult education at the post graduate levels.

3. Examine the level of awareness of lecturers in Adult and Non-Formal Education Departments in selected Universities in Nigeria on heutagogy as a teaching and learning approach for $21^{\text {st }}$ century adult educators.

\section{Research Questions}

1. To what level do lecturers in Adult and Non-Formal Education Departments in selected Universities in Nigeria engage in pedagogical teaching and learning at the post graduate class?

2. What are the opinions of lecturers in Adult and NonFormal Education Departments in selected Universities in Nigeria on changing pedagogies in teaching and learning of adult education at the post graduate levels?

3. To what level are lecturers in Adult and Non-Formal Education Departments in selected Universities in Nigeria are awareness of heutagogy as a teaching and learning approach for $21^{\text {st }}$ century adult educators.

\section{LITERATURE REVIEW}

\section{Pedagogy}

Pedagogy is a teacher centered approach to teaching and learning which helps learners to develop high-order thinking skills. Pedagogy according to Knowles (1980) assumes that a student is ready to learn specific concepts at certain ages and grades and that the motivation behind a student's desire to learn in a pedagogical framework is based off external pressures such as feelings of fear, failure, or social rejection. To Léon-Henri (2021), pedagogy is more related to the correlation between the teaching material (resources) or theoretical information (methods) and the intellectual capacity of students, as well as their individual needs. Based on this assumption, Léon-Henri (2021) defined pedagogy as the method and practice of teaching and instruction, that matches theoretical concepts (didactics of teaching and instruction) with practical methods (pedagogy) of knowledge transfer in education which can be true for any given field of study. Cole (2019) explained that pedagogy in education can either be teacher-centered or learner-centered with a low-tech or hightech approach. Knowles (1980) pointed out that learners in a pedagogical framework see education as a process of acquiring subject-matter content, most of which they understand will be useful only at a later time in life.

Teacher-centered learning of pedagogy according to Cole (2019) focuses on the teacher giving lectures and sharing content through direct instruction. Teacher-centered learning of pedagogy fixates on the knowledge the teacher has and the teacher imparting that knowledge to students. While the student-centered learning of pedagogy according to Cole (2019) directs the student to be an active participant in their own learning process but the teacher still delivers content, they take on more of a coaching or mentoring role to help students learn. Student-centered assessments are given more frequently to assess knowledge and tend to be more objective. There are four common forms of pedagogy according to (nd) social (education as supporting social development), critical (deconstructing normative perspectives), culturally responsive (encouraging the sharing of diverse backgrounds and experiences) and Socratic (developing intellectual and social skills to live in a democratic society). In pedagogical teaching 
and learning, a teacher is called a pedagogue, A pedagogue refers to someone who is capable of making a perfect match and succeeding in the act of knowledge transfer inside or outside the classroom. It is worthy of note that pedagogy in the $21^{\text {st }}$ century is no longer for only cognitive development and understanding but it has expanded to the inclusion of development of competence.

\section{Pedagogies in Teaching and Learning in Adult Education}

Pedagogical approaches are still employed in the teaching and learning of adult education, most lecturers in adult education departments in Universities offering adult education in Nigeria still adopt the pedagogical approach that is based on banking theory proposed by Freire.Freire (2000) introduced the idea of banking concept when explaining the concept of oppression. Accordingly, Freire (2000) observed that "banking concept shares commonality with pedagogy in several elements, that in banking concept, teachers educate students by "depositing" into them. Students are empty vessels, and the teacher consistently makes deposits of information to the student, limiting student actions "only as far as receiving, filing, and storing the deposits" (p.5). This lack of student engagement and critical thinking in classrooms occurs throughout higher education. Usage of pedagogical assumptions by lecturerlimits learner's experience and inadvertently subscribe to banking theory by using their authority as teachers to deposit knowledge and avoid anything aside from their role of depositing knowledge. Freire (2008) stated that:

\section{Implicit in the banking concept is the assumption of a dichotomy between human beings and the world: a person is merely in the world, not with the world or with others; the individual is a spectator, not re- creator. In this view the person is not a conscious being (corpoconsciente); he or she is rather the possessor of a consciousness: an empty "mind" passively open to the reception of deposits of reality from the world outside, (Freire, 2008, p.254)}

The view of Freire above, explained that the banking concept imposes a schism between a person (teacher and/or student) and the "real world", resulting in the evident demise of his or her true consciousness, since the former can only be realized through the relationships and connections the individual draws from the material to their life. In support of this Micheletti (2010,p.1) observed that "Freire claims of assuming the roles of teachers as depositors and students as receptors", exemplified the banking concept thereby changes humans into objects. Humans (as objects) have no autonomy and therefore no ability to rationalize and conceptualize knowledge at a personal level. And because of this initial misunderstanding, the method itself is a system of oppression and control. In order to alleviate the "dehumanization" produced by the banking concept". Micheletti (2010) further explained that:

Freire introduces what is deemed as "problemposing education". In this approach the roles of students and teachers become less structured, and both engage in acts of dialogic enrichment to effectively ascertain knowledge from each other. According to Freire, "Knowledge emerges only through invention and re-invention, through the restless, impatient, continuing, hopeful inquiry human beings pursue in the world, with the world, and with each other, (Micheletti, 2010, p.1)

In post graduate programmes in most Nigeria Universities, lectures in the various departments of adult education in Nigeria pedagogy still teach post graduate students who are prospective professional adult educators with pedagogical approach.Utilizing pedagogy in teaching and learning at graduate level is a continuous way of oppressing the student as explained by Freire in his banking concept because students produced yearly with theseassumptions, become accustomed to them, and in turn, believe that these assumptions are absolutes for education. Students under this assumption according to Micheletti (2010) are meant to believe that the teacher provides them with all of the learning needed, and that to become a master of a topic, they must earn a degree.It is worthy of note that by continuing to teach students with pedagogical approaches, will only make the students master of knowledge and at same time deny them the ability to move toward being more self-directed and independent. In view of this, Torres (1994)corroborated that"most college professors "do not address objective reality" rather they are more focused on objective reality as contained in the books and journals, that college Professors turn their book-initiated reality into "the object of knowledge, within (the) struggle for power, focusing upon accumulated knowledge", (p.23).

Furthermore, Torres (1994) observed thatfor higher education to become a genuine platform for adult learners, it must reject the guidelines received from our ancestors and free itself from the entrapment of "experts" as contained in books and journals. He also suggested that though pedagogy has its uses, but to genuinely free adult learners from the previous assumptions regarding students, we need to change our teaching and learning practices to an intentional model designed to serve our students better and free them from oppression (banking concept). Freeing students mostly at post graduate level from the oppression as explained by Freire required university lecturers changing their teaching and learning approach to a more self-directed and self-determined teaching and learning approach that heutagogy posit.In support of this, Kuit and Fell (2010, p, 10 and The World Bank, 2003 ) pointed out that"educators today are tasked with developing lifelong learners who can survive and thrive in a global knowledge economy, that is producing learners who have the capability to effectively and creatively apply skills and competencies to new situations in an ever-changing, complex world".

\section{Concept of Heutagogy}

Heutagogy is based on humanistic philosophy which is rooted in andragogy (self-directed learning) with extension of 
developing the capabilities in learners to meet up the changes in human learning, which $21^{\text {st }}$ century brought to education. Students at the Universities in this $21^{\text {st }}$ century is expected to learn how to learn, this will allow them to put together their own beliefs (to be self-determined learners) and also develop capabilities to tackle challenges. Heutagogy was first defined by two Australia scholars, Hase and Kenyon in 2000, as the study of self-determined learning. The theory applies a holistic, humanistic approach to developing learner capacity and capability and makes learners "the major agent in their own learning, which occurs, as a result of personal experience". Heutagogyaccording to Blaschke (2012) "is a form of self-determined learning with practices and principles rooted in andragogy, in which learners are highly autonomous and self-determined; and emphasis is placed on development of learner capacity and capability with the goal of producing learners who are well-prepared for the complexities of today's workplace". According to Bhoryrub, Hurley, Neilson, Ramsay, \& Smith (2010), "aheutagogical learning environment facilitates development of capable learners and emphasizes both the development of learner competencies as well as development of the learner's capability and capacity to learn".Hase and Kenyon (2000) defined heutagogy as "the study of self-determined learning, which applies a holistic approach to developing learner capabilities, with learning as an active and proactive process, and learners serving; which attempt to challenge some ideas about teaching and learning that still prevail in teacher centered learning and the need for what Bill Ford (1997) called 'knowledge sharing' rather than 'knowledge hoarding". Accordingly, Hase and Kenyon (2001) observed that there is another revolution taking place in educational circles that appears to go one step beyond andragogy. This revolution:

1. Is based on a new set of principles and practices that may have application across the whole spectrum of the education and learning lifespan

2. It recognizes the changed world in which we live: A world in which:

a. Information is readily and easily accessible;

b. Change is so rapid that traditional methods of training and education are totally inadequate;

c. Discipline-based knowledge is inappropriate to prepare for living in modern communities and workplaces;

d. Learning is increasingly aligned with what we do;

e. Modern organisational structures require flexible learning practices; and

f. There is a need for immediacy of learning. Hase and Kenyon (2001, p.62)

However, heutagogy from their point of view look to the future in which knowing how to learn will be a fundamental skill given the pace of innovation and the changing structure of communities and workplaces. Accordingly, heutagogyis the study of self-determined learning which is a natural progression from earlier educational methodologies, that develop capability in learners and they suggested that heutagogy is appropriate to the needs of learners in the workplace in the twenty-first century, particularly in the development of individual capability. Canning (2010) established that "heutagogy is a continuum of andragogy (self-directed learning), the study of teaching and learning for also known as the PAH continuum (Pedagogy-AndragogyHeutagogy Continuum)", (p.63). Garnett (2013) a proponent of PAH continuum, argued that a greater level of learner maturity and self-organization is required in order to advance through the continuum, that as learners become less dependent upon the instructor for guidance and structure within the learning process (pedagogy), they are able to advance through the continuum to more autonomous and less structured learning environments. This is shown in fig 1 :

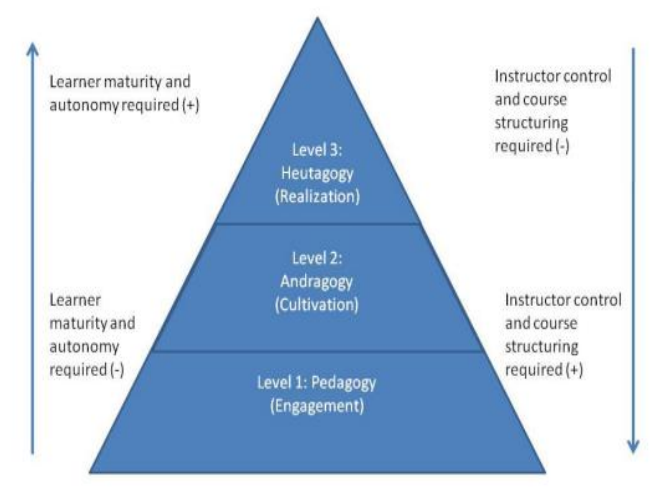

$$
\begin{aligned}
& \text { Figure 1. Progression from pedagogy to andragogy then to heutagogy (Blaschke, 2012, p. 60, based on Canning, } \\
& \text { 2010, p. 63). }
\end{aligned}
$$

At Pedagogy Level: Instructors are firmly in control of the learning process, working toward motivating students to engage in learning content.

At Andragogy Level: The instructor begins to cultivate the learner's ability to self-direct his or her learning, allowing him or her more freedom in directing how learning occurs and providing less structure in the course design. However, the instructor is still the primary agent in the learning process, continuing to scaffold and construct the learning experience, while allowing a higher degree of learner autonomy.

At Heutagogy Level: The learner assumes full control of his or her learning and is granted complete autonomy in deciding how he or she will learn. (Canning, 2010, p.62).

Blaschke (2012) also explained heutagogy as a continuum of andragogy with the following features:

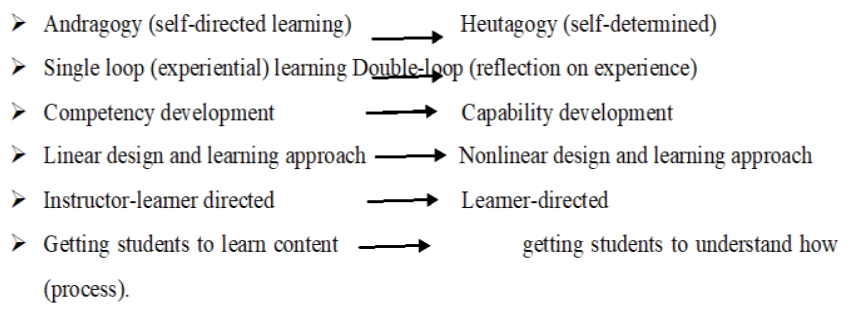


Blaschke (2012) asserted that heutagogy enables the development of capable learners and accentuates the development of learner competencies as well as their capabilities and capacity to learn. This is in support of Canning (2010) view that developing heutagogy meant creating a self-directed learning environment for students to discover their own strategies for learning. Hase and Kenyon (2001) also averred that a heutagogical approach recognises the need to be flexible in the learning where the teacher provides resources but the learner designs the actual course he or she might take by negotiating the learning that as teachers we should concern ourselves with developing the learner's capability not just embedding discipline based skills and knowledge.

\section{Principles of Heutagogy}

Principles of heutagogy as coined out by Blaschke (2016)are human agency (learner-centeredness), capability, selfreflection and metacognition (double-loop learning), and nonlinear teaching and learning

Human agency: Within heutagogic learning environment, the learner is the agent or driver of his or her learning, learners are given complete responsibility of the learning process and determine what they will learn and the way in which they will learn and ultimately assess the success of their learning, Hase and Kenyon (2013). In a heutagogic learning environment as observed by Pink in Hase and Kenyon (2013), learners become the drivers of the learning process which requires that learners are to be highly autonomous rather than oppressing them, which can then help them feel more competent and in turn promote development of intrinsic and self-motivation.

Capability: Heutagogy create capable learners who are well equipped for the demands of complex and changing work environments. Capable learners exhibit their capabilities by applying skills and knowledge in new and unfamiliar situations or contexts.

Self-Reflection and Metacognition (Double-Loop Learning): Having an understanding of how they learn is essential in order for learners to be successful in adopting self-determined learning. This reflection occurs in a holistic way, with learners reflecting on the new knowledge that they have acquired, as well as the way in which they have acquired it, (Blaschke, 2016). Schön in Blaschke (2016) contended that learners and future employees must become reflective practitioners and adopt certain practices in order to be able to adapt to the demands of the workplace. Reflective practitioner according to him is one who is able to know-in action apply what is learned in making decisions); reflect-in-action (think about an activity as it is being carried out); and reflect-in-practice (consider the activity that has been carried out and how it has been done so, while applying corrective action.

Double-Loop Learning: In double-loop learning, learner sets out to find a solution to a problem by first identifying a problem, then potential actions, evaluates outcomes and then considers the steps taken to learn through self-reflection.

Non-Linear Teaching and Learning: Learner is responsible for learning and defines the learning pathway; as each learner's experiences and mental model varies, the path taken can be divergent and unpredictable (Long, 1990). When learners practice non-linear learning, instruction must also be adapted. Instructors in non-linear teaching and learning according to Hase (2014) plays the role of learning leaders, exhibiting characteristics such as the ability to handle ambiguity, the capacity to nurture learner engagement and to learn themselves, and the capability of applying open systems.

\section{Difference between Pedagogy and Heutagogy in Teaching and Learning}

Pedagogy is a teacher centered or teacher-led teaching and learning in which the teacher determines what the students will learn and how they will learn it. Students are depended on their teachers during the teaching learning transaction in which the teacher present topics of instruction in the order they want the students to learn. While in heutagogical teaching and learning, students are encouraged to find their own problems and answer to questions, teacher assign task to students provide them with context to learning and create opportunities for them to explore subjects fully. The teachers are facilitators of learning in heutagogical teaching and learning while the student owns the learning path process and negotiates it and this determines what will be learned and how it will be learned. The difference is presented in table 1.

Table 1: Difference between Pedagogy and Heutagogy in Teaching and Learning

\begin{tabular}{|c|c|c|}
\hline & $\begin{array}{c}\text { Pedagogy (Children's } \\
\text { Learning) }\end{array}$ & $\begin{array}{c}\text { Heutagogy (Self-Directed } \\
\text { Learning) }\end{array}$ \\
\hline Dependence & $\begin{array}{l}\text { The learner is a } \\
\text { dependent personality. } \\
\text { Teacher determines } \\
\text { what, how, and when } \\
\text { anything is learned. }\end{array}$ & $\begin{array}{l}\text { Learners are interdependent. They } \\
\text { identify the potential to learn from } \\
\text { novel experiences as a matter of } \\
\text { course. They are able to manage } \\
\text { their own learning }\end{array}$ \\
\hline $\begin{array}{l}\text { Resources } \\
\text { for learning }\end{array}$ & $\begin{array}{l}\text { The learner has few } \\
\text { resources. The teacher } \\
\text { devises transmission } \\
\text { techniques to store } \\
\text { knowledge in the } \\
\text { learner's head. }\end{array}$ & $\begin{array}{l}\text { Teacher provides some resources, } \\
\text { but the learner decides the path by } \\
\text { negotiating the learning. }\end{array}$ \\
\hline $\begin{array}{l}\text { Reasons for } \\
\text { learning }\end{array}$ & $\begin{array}{l}\text { Learn in order to } \\
\text { advance to the next } \\
\text { stage. }\end{array}$ & $\begin{array}{l}\text { Learning is not necessarily planned } \\
\text { or linear. Learning is not } \\
\text { necessarily based on need but on } \\
\text { the identification of the potential to } \\
\text { learn in novel situations. }\end{array}$ \\
\hline $\begin{array}{l}\text { Focus of } \\
\text { learning }\end{array}$ & $\begin{array}{l}\text { Learning is subject } \\
\text { centered, focused on the } \\
\text { prescribed curriculum } \\
\text { and planned sequences } \\
\text { according to the logic of } \\
\text { the subject matter. }\end{array}$ & $\begin{array}{l}\text { Learners can go beyond problem } \\
\text { solving by enabling pro-activity. } \\
\text { Learners use their own and others' } \\
\text { experiences and internal processes } \\
\text { such as reflection, environmental } \\
\text { scanning, experience, interaction } \\
\text { with others, and pro-active as well } \\
\text { a problem-solving behavior. }\end{array}$ \\
\hline Motivation & $\begin{array}{l}\text { Motivation comes from } \\
\text { external sourcesusually } \\
\text { parents, teachers, and a } \\
\text { sense of competition. }\end{array}$ & $\begin{array}{l}\text { Self-efficacy, knowing how to } \\
\text { learn, creativity, ability to use these } \\
\text { qualities in novel as well as } \\
\text { situations, and working with others. }\end{array}$ \\
\hline
\end{tabular}




\begin{tabular}{|c|c|c|}
\hline \multirow{7}{*}{$\begin{array}{l}\text { Role of the } \\
\text { teacher }\end{array}$} & \multirow{7}{*}{$\begin{array}{l}\text { Designs the learning } \\
\text { process, imposes } \\
\text { material, is assumed to } \\
\text { know best. }\end{array}$} & $\begin{array}{l}\text { Develop the learner's capability. } \\
\text { Capable people: }\end{array}$ \\
\hline & & $>\quad$ Know how to learn \\
\hline & & Are creative \\
\hline & & $>\quad$ Have a high degree of \\
\hline & & self-efficacy \\
\hline & & $\begin{array}{l}\text { Apply competencies in } \\
\text { novel as well as familiar situations }\end{array}$ \\
\hline & & $\begin{array}{l}>\quad \text { Can work well with } \\
\text { others }\end{array}$ \\
\hline
\end{tabular}

Adapted from Garstein work on education 3.0 and the pedagogy of mobile learning

\section{METHODOLOGY}

The study adopted descriptive survey design. The choice of descriptive design was based on the fact that the researcher aimed at identifying, observing and measuring the variables in this study without manipulating it. The population of the study was lecturers in the department of adult education in Universities in South-South Geopolitical Zone of Nigeria. The purposive sampling technique was used to sample on those lecturers that teach and supervise post graduate students. The instrument used for data collection is a structured for point Likert- scale questionnaire rated as very high level (VHL), high level (HL), low level (LL), and very low level (VLL) designed with google form. The instrument was subjected to face and construct validity. It was also tested for reliability. Data was collected via electronic mailing, the designed google form-based questionnaire was sent to respondent emails and group WhatsApp chats. Data collected was analysed with descriptive statistics (frequency, percentages, mean and standard deviation). Criterion mean of 2.5 was used for decisions on each of the responses, any mean scores lesser than 2.5 is taken to be negative while any mean score that is equal or greater than 2.5 is regarded as positive response.

\section{RESULTS}

Research Question One: To what level do lecturers in Adult and Non-Formal Education Departments in selected Universities in Nigeria engage in pedagogical teaching and learning at the post graduate class?

Table 2: Analysis of Level to Which Lecturers Engage in Pedagogical Teaching and Learningat the Post Graduate Levels

\begin{tabular}{|c|c|c|c|c|c|c|c|c|c|}
\hline \multicolumn{10}{|c|}{ Level to Which Lecturers Engage in Pedagogical Teaching and Learningat the Post Graduate Levels } \\
\hline $\mathrm{S} / \mathrm{N}$ & Statements & VHL & HL & LL & VLL & Total & $\mathrm{X}$ & $\mathrm{SD}$ & Decision \\
\hline 1 & $\begin{array}{l}\text { As a lecturer that teach post graduate students, you still } \\
\text { determine how and when your student learn }\end{array}$ & $\begin{array}{c}35 \\
(140)\end{array}$ & $\begin{array}{c}16 \\
(48)\end{array}$ & $\begin{array}{c}4 \\
(8)\end{array}$ & $\begin{array}{c}2 \\
(2)\end{array}$ & $\begin{array}{c}57 \\
(198)\end{array}$ & 3.5 & 0.78 & High Level \\
\hline 2 & $\begin{array}{l}\text { Your post graduate students still depend on you to give them } \\
\text { notes when teaching }\end{array}$ & $\begin{array}{c}20 \\
(80)\end{array}$ & $\begin{array}{l}30 \\
(90)\end{array}$ & $\begin{array}{l}3 \\
(6)\end{array}$ & $\begin{array}{c}4 \\
(4)\end{array}$ & $\begin{array}{c}57 \\
(180)\end{array}$ & 3.2 & 0.81 & High Level \\
\hline 3 & $\begin{array}{l}\text { You still provide your students with learning materials and } \\
\text { read for them in class }\end{array}$ & $\begin{array}{c}28 \\
(112)\end{array}$ & $\begin{array}{c}22 \\
(66)\end{array}$ & $\begin{array}{c}5 \\
(10)\end{array}$ & $\begin{array}{c}2 \\
(2)\end{array}$ & $\begin{array}{c}57 \\
(190)\end{array}$ & 3.3 & 0.78 & High Level \\
\hline 4 & $\begin{array}{l}\text { You are always at the center of the teaching learning } \\
\text { transaction, by storing knowledge in your student head }\end{array}$ & $(28)$ & $\begin{array}{c}21 \\
(63)\end{array}$ & $\begin{array}{c}5 \\
(10)\end{array}$ & $\begin{array}{c}3 \\
(3)\end{array}$ & $\begin{array}{c}57 \\
(188)\end{array}$ & 3.3 & 0.84 & High Level \\
\hline 5 & $\begin{array}{l}\text { You still impose materials on your student, making them to } \\
\text { feel that the material you provided for them is the only source } \\
\text { of knowledge }\end{array}$ & $\begin{array}{c}34 \\
(136)\end{array}$ & $\begin{array}{c}20 \\
(60)\end{array}$ & $\begin{array}{l}3 \\
(6)\end{array}$ & - & $\begin{array}{c}57 \\
(202)\end{array}$ & 3.5 & 0.59 & High Level \\
\hline 6 & $\begin{array}{l}\text { During your teaching learning transaction, you don't allow } \\
\text { student to take the center stage by contributing their opinion }\end{array}$ & $\begin{array}{c}19 \\
(76)\end{array}$ & $\begin{array}{c}25 \\
(75) \\
\end{array}$ & $\begin{array}{c}5 \\
(10) \\
\end{array}$ & $\begin{array}{c}3 \\
(3)\end{array}$ & $\begin{array}{c}57 \\
(169) \\
\end{array}$ & 2.9 & 0.99 & High Level \\
\hline 7 & $\begin{array}{l}\text { You do allow students to go and carry out research on topics } \\
\text { and then present the instruction in the class }\end{array}$ & $\begin{array}{c}27 \\
(108)\end{array}$ & $\begin{array}{c}19 \\
(57)\end{array}$ & $\begin{array}{c}6 \\
(12)\end{array}$ & $\begin{array}{c}5 \\
(5)\end{array}$ & $\begin{array}{c}57 \\
(186)\end{array}$ & 3.3 & 0.83 & High Level \\
\hline 8 & $\begin{array}{l}\text { You do not expose your students to contents that are outside } \\
\text { he prescribed curriculum to enable them acquaint themselves } \\
\text { with new knowledge outside their field of study. }\end{array}$ & $\begin{array}{c}26 \\
(104)\end{array}$ & $\begin{array}{l}23 \\
(69)\end{array}$ & $\begin{array}{c}5 \\
(10)\end{array}$ & $\begin{array}{c}3 \\
(3)\end{array}$ & $\begin{array}{c}57 \\
(182)\end{array}$ & 3.1 & 0.95 & High Level \\
\hline 9 & You involve your students in the design of the learning process & $\begin{array}{c}19 \\
(76)\end{array}$ & $\begin{array}{l}25 \\
(75)\end{array}$ & $\begin{array}{c}7 \\
(14)\end{array}$ & $\begin{array}{c}6 \\
(6)\end{array}$ & $\begin{array}{c}57 \\
(171)\end{array}$ & 3.0 & 0.94 & High Level \\
\hline \multirow[t]{2}{*}{10} & $\begin{array}{l}\text { You provide textbook and other learning material for your } \\
\text { student }\end{array}$ & $\begin{array}{c}21 \\
(84)\end{array}$ & $\begin{array}{c}32 \\
(96)\end{array}$ & $\begin{array}{c}2 \\
(4)\end{array}$ & $\begin{array}{c}2 \\
(2)\end{array}$ & $\begin{array}{c}57 \\
(186)\end{array}$ & 3.3 & 0.69 & High Level \\
\hline & Grand Mean & & & & & & 3.2 & 0.82 & High Level \\
\hline
\end{tabular}

Table2 show that respondent responses on items 1-10 gave mean scores that ranges 2.9-3.5, with corresponding standard deviations that ranges from 0.59-0.99, the mean scores are greater than 2.5 which is the criterion mean and implies a positive response. In the table, a grand mean score of 3.2 was arrived at, this is also greater than 2.5 criterion mean and implies that lecturers that teaches post graduate students in Adult and Non-Formal Education Departments in Nigeria Universities still to a high level still in engage in pedagogical teaching and learning in their post graduate class. 
Research Question Two: What are the opinions of lecturers in Adult and Non-Formal Education Departments in selected
Universities in Nigeria on changing pedagogies in teaching and learning of adult education at the post graduate levels?

Table 3: Analysis of Opinions of Lecturers on Changing Pedagogies in Teaching and Learning of Adult Education at the Post Graduate Levels

\begin{tabular}{|c|c|c|c|c|c|c|c|c|c|}
\hline & \multicolumn{9}{|c|}{ Opinions of Lecturers on Changing Pedagogies in Teaching and Learning of at the Post Graduate Levels } \\
\hline $\mathrm{S} / \mathrm{N}$ & Statements & VHL & HL & LL & VLL & Total & $\mathrm{X}$ & SD & Decision \\
\hline 11 & $\begin{array}{l}\text { Pedagogical teaching and learning is no longer a good } \\
\text { approach for teaching post graduate students of the } \\
\text { present knowledge economy and thus required to be } \\
\text { changed }\end{array}$ & $\begin{array}{c}29 \\
(116)\end{array}$ & $\begin{array}{c}20 \\
(60)\end{array}$ & $\begin{array}{c}5 \\
(10)\end{array}$ & $\begin{array}{c}3 \\
(3)\end{array}$ & $\begin{array}{c}57 \\
(189)\end{array}$ & 3.3 & 0.84 & High Level \\
\hline 12 & $\begin{array}{l}\text { Teacher centeredness kind of teaching that pedagogy is } \\
\text { all about limits graduate student potential to show case } \\
\text { their capabilities and thus required to be changed }\end{array}$ & $\begin{array}{c}18 \\
(72)\end{array}$ & $\begin{array}{c}33 \\
(99)\end{array}$ & $\begin{array}{c}4 \\
(8)\end{array}$ & $\begin{array}{c}2 \\
(2)\end{array}$ & $\begin{array}{c}57 \\
(181)\end{array}$ & 3.1 & 0.71 & High Level \\
\hline 13 & $\begin{array}{l}\text { Pedagogical teaching and learning make learners } \\
\text { independent on lectures as reservoir of knowledge and } \\
\text { thus required to be changed }\end{array}$ & $\begin{array}{c}5 \\
(20)\end{array}$ & $\begin{array}{c}46 \\
(138)\end{array}$ & $\begin{array}{c}5 \\
(10)\end{array}$ & $\begin{array}{c}1 \\
(1)\end{array}$ & $\begin{array}{c}57 \\
(169)\end{array}$ & 2.9 & 0.50 & High Level \\
\hline 14 & $\begin{array}{l}\text { Pedagogical teaching and learning deny student the } \\
\text { capability to identify their potentials and thus required } \\
\text { to be changed }\end{array}$ & $\begin{array}{c}11 \\
(44)\end{array}$ & $\begin{array}{c}39 \\
(117)\end{array}$ & $\begin{array}{c}5 \\
(10)\end{array}$ & $\begin{array}{c}2 \\
(2)\end{array}$ & $\begin{array}{c}57 \\
(173)\end{array}$ & 3.0 & 0.65 & High Level \\
\hline 15 & $\begin{array}{l}\text { Under present pedagogical teaching and learning, } \\
\text { students cannot manage their own learning and thus } \\
\text { required to be changed }\end{array}$ & $\begin{array}{c}15 \\
(60)\end{array}$ & $\begin{array}{c}34 \\
(102)\end{array}$ & $\begin{array}{c}6 \\
(12)\end{array}$ & $\begin{array}{c}2 \\
(2)\end{array}$ & $\begin{array}{c}57 \\
(176)\end{array}$ & 3.1 & 0.71 & High Level \\
\hline 16 & $\begin{array}{l}\text { Planning learning in a linear format that pedagogical } \\
\text { approach entails does not allow identification of } \\
\text { potential to learn among student for present knowledge } \\
\text { economy and thus required to be changed }\end{array}$ & $\begin{array}{c}14 \\
(56)\end{array}$ & $\begin{array}{c}31 \\
(93)\end{array}$ & $\begin{array}{c}5 \\
(10)\end{array}$ & $\begin{array}{c}6 \\
(1)\end{array}$ & $\begin{array}{c}57 \\
(165)\end{array}$ & 2.9 & 0.88 & High Level \\
\hline 17 & $\begin{array}{l}\text { Students at post graduate level are expected to be pro- } \\
\text { active, gong beyond problem solving to environmental } \\
\text { scanning in knowledge economy, which pedagogical } \\
\text { teaching and learning did not allow them to be }\end{array}$ & $\begin{array}{c}10 \\
(40)\end{array}$ & $\begin{array}{c}38 \\
(114)\end{array}$ & $\begin{array}{c}6 \\
(12)\end{array}$ & $\begin{array}{c}3 \\
(3)\end{array}$ & $\begin{array}{c}57 \\
(169)\end{array}$ & 2.9 & 0.71 & High Level \\
\hline 18 & $\begin{array}{l}\text { Pedagogical teaching and learning adopted in teaching } \\
\text { and learning of post graduate students in our Nigeria } \\
\text { universities does not allow students to use their } \\
\text { experiences and that of their colleagues to develop a } \\
\text { pro-active problem solving behaviour and thus required } \\
\text { to be changed }\end{array}$ & $\begin{array}{c}8 \\
(32)\end{array}$ & $\begin{array}{c}37 \\
(111)\end{array}$ & $\begin{array}{c}7 \\
(14)\end{array}$ & $\begin{array}{c}5 \\
(5)\end{array}$ & $\begin{array}{c}57 \\
(162)\end{array}$ & 2.8 & 0.77 & High Level \\
\hline 19 & $\begin{array}{l}21^{\text {st }} \text { century knowledge economy requires not only } \\
\text { bringing up student that are cognitive loaded but } \\
\text { students that are creative and capable to fit in with } \\
\text { challenges associated the changing societies which } \\
\text { pedagogical teaching and learning does not proffer }\end{array}$ & $\begin{array}{c}33 \\
(132)\end{array}$ & $\begin{array}{c}14 \\
(42)\end{array}$ & $\begin{array}{c}5 \\
(10)\end{array}$ & $\begin{array}{c}5 \\
(5)\end{array}$ & $\begin{array}{c}57 \\
(189)\end{array}$ & 3.3 & 0.96 & High Level \\
\hline 20 & $\begin{array}{l}\text { Pedagogical teaching and learning utilize for teaching } \\
\text { post graduate students does not give the students the } \\
\text { room to apply competencies. }\end{array}$ & $\begin{array}{c}15 \\
(60)\end{array}$ & $\begin{array}{c}35 \\
() 105\end{array}$ & $\begin{array}{c}5 \\
(10)\end{array}$ & $\begin{array}{c}2 \\
(2)\end{array}$ & $\begin{array}{c}57 \\
(177)\end{array}$ & 3.1 & 0.69 & High Level \\
\hline & Grand Mean & & & & & & 3.0 & 0.74 & High Level \\
\hline
\end{tabular}

In table 3 Respondents responses on items 11-20 gave mean scores that ranges from 2.8-3.3 with corresponding standard deviations of that ranges from $0.50-0.96$. The mean scores are all greater than the 2.5 criterion mean and implies a positive response. With a grand mean of 3.0 which is also greater than the criterion mean, respondent responses on table 2 implies that lecturers in Adult and Non-Formal Education Departments in selected Universities in Nigeria were to a high level of the opinion that there is need to change pedagogies in teaching and learning of adult education students mostly at the post graduate level to fit in with the challenges involve in the changes associated with the present knowledge economy.

Research Question Three: To what level are lecturers in Adult and Non-Formal Education Departments in selected Universities in Nigeria are awareness of heutagogy as a teaching and learning approach for $21^{\text {st }}$ century learners. 
Table4: Analysis of Level to Which Lecturers are Awareness of Heutagogy as a Teaching and Learning Approach for $21^{\text {st }}$ Century Learners

\begin{tabular}{|c|c|c|c|c|c|c|c|c|c|}
\hline \multicolumn{10}{|c|}{ Level of Lecturers Awareness of Heutagogy as a Teaching and Learning Approach for $21^{\text {st }}$ Century Learners } \\
\hline $\mathrm{S} / \mathrm{N}$ & Statements & VHL & HL & LL & VLL & Total & $\mathrm{X}$ & SD & Decision \\
\hline 21 & $\begin{array}{l}\text { You have read about heutagogy approach to teaching and } \\
\text { learning as } 21^{\text {st }} \text { century teaching and learning approach }\end{array}$ & $\begin{array}{c}10 \\
(40)\end{array}$ & $\begin{array}{c}13 \\
(39) \\
\end{array}$ & $\begin{array}{c}16 \\
(32) \\
\end{array}$ & $\begin{array}{l}18 \\
(18) \\
\end{array}$ & $\begin{array}{c}57 \\
(129) \\
\end{array}$ & 2.2 & 1.09 & Low Level \\
\hline 22 & $\begin{array}{l}\text { You have been utilizing heutagogy approach to teaching and } \\
\text { learning of your post graduate students in order to expose } \\
\text { them changes pose by the changes in the knowledge world } \\
\text { and society at large }\end{array}$ & $\begin{array}{c}5 \\
(20)\end{array}$ & $\begin{array}{c}8 \\
(24)\end{array}$ & $\begin{array}{l}32 \\
(64)\end{array}$ & $\begin{array}{c}12 \\
(12)\end{array}$ & $\begin{array}{c}57 \\
(120)\end{array}$ & 2.1 & 0.84 & Low Level \\
\hline 23 & $\begin{array}{l}\text { You are aware that as a lecturer teaching post-graduate } \\
\text { students in the present } 21^{\text {st }} \text { century, that you were supposed to } \\
\text { facilitate learning while the students owns the learning path } \\
\text { process and negotiates it. }\end{array}$ & $\begin{array}{c}7 \\
(28)\end{array}$ & $\begin{array}{c}6 \\
(18)\end{array}$ & $\begin{array}{c}18 \\
(32)\end{array}$ & $\begin{array}{c}26 \\
(26)\end{array}$ & $\begin{array}{c}57 \\
(108)\end{array}$ & 1.9 & 1.03 & Low Level \\
\hline 24 & $\begin{array}{l}\text { You are aware that you as a facilitator at the post-graduate } \\
\text { teaching and learning, is supposed to always assign task to } \\
\text { your student in order to create the opportunities for them to } \\
\text { explore the subject area fully }\end{array}$ & $\begin{array}{c}3 \\
(12)\end{array}$ & $\begin{array}{c}8 \\
(24)\end{array}$ & $\begin{array}{c}22 \\
(44)\end{array}$ & $\begin{array}{c}24 \\
(24)\end{array}$ & $\begin{array}{c}57 \\
(104)\end{array}$ & 1.8 & 0.87 & Low Level \\
\hline 25 & $\begin{array}{l}\text { You are aware that in heutagogy, students determine what } \\
\text { will be learned and how it will be learned }\end{array}$ & $\begin{array}{c}5 \\
(20)\end{array}$ & $\begin{array}{l}3 \\
(9) \\
\end{array}$ & $\begin{array}{c}24 \\
(48)\end{array}$ & $\begin{array}{c}25 \\
(25)\end{array}$ & $\begin{array}{c}57 \\
(102)\end{array}$ & 1.8 & 0.90 & Low Level \\
\hline 26 & $\begin{array}{l}\text { You are aware that in heutagogy, students are to be } \\
\text { encouraged to find their own problems and answers to the } \\
\text { questions the problem raises }\end{array}$ & $\begin{array}{c}8 \\
(40)\end{array}$ & $\begin{array}{c}7 \\
(21)\end{array}$ & $\begin{array}{l}32 \\
(64)\end{array}$ & $\begin{array}{c}10 \\
(10)\end{array}$ & $\begin{array}{c}57 \\
(127)\end{array}$ & 2.2 & 0.91 & Low Level \\
\hline 27 & $\begin{array}{l}\text { In heutagogy approach, learning is not necessarily based on } \\
\text { need but on the identification of the potential to learn in novel } \\
\text { situations. }\end{array}$ & $\begin{array}{c}2 \\
(8)\end{array}$ & $\begin{array}{c}13 \\
(39)\end{array}$ & $\begin{array}{l}23 \\
(46)\end{array}$ & $\begin{array}{c}19 \\
(19)\end{array}$ & $\begin{array}{c}57 \\
(112)\end{array}$ & 1.9 & 0.84 & Low Level \\
\hline 28 & $\begin{array}{l}\text { Heutagogy approach help student to develop their capability } \\
\text { to know how to learn }\end{array}$ & $\begin{array}{c}7 \\
(28) \\
\end{array}$ & $\begin{array}{c}8 \\
(32)\end{array}$ & $\begin{array}{c}24 \\
(48)\end{array}$ & $\begin{array}{c}18 \\
(18)\end{array}$ & $\begin{array}{c}57 \\
(116) \\
\end{array}$ & 2.1 & 0.98 & Low Level \\
\hline 29 & $\begin{array}{l}\text { In heutagogy approach, learners can go beyond problem } \\
\text { solving by enabling pro-activity }\end{array}$ & $\begin{array}{c}2 \\
(8)\end{array}$ & $\begin{array}{c}6 \\
(18) \\
\end{array}$ & $\begin{array}{c}29 \\
(58) \\
\end{array}$ & $\begin{array}{c}20 \\
(20) \\
\end{array}$ & $\begin{array}{c}57 \\
(104) \\
\end{array}$ & 1.8 & 0.98 & Low Level \\
\hline 30 & $\begin{array}{l}\text { In heutagogy approach learner use their own and others' } \\
\text { experiences and internal processes such as reflection, } \\
\text { environmental scanning, experience, interaction with others, } \\
\text { and pro-active as well a problem-solving behavior. }\end{array}$ & $\begin{array}{c}6 \\
(24)\end{array}$ & $\begin{array}{c}7 \\
(21)\end{array}$ & $\begin{array}{c}31 \\
(62)\end{array}$ & $\begin{array}{c}14 \\
(14)\end{array}$ & $\begin{array}{c}57 \\
(117)\end{array}$ & 2.0 & 0.76 & Low Level \\
\hline & Grand Mean & & & & & & 2.0 & 0.91 & Low Level \\
\hline
\end{tabular}

Table 4 show that respondent responses for items 21-30 gave mean scores that ranges from 1.8-2.2 with corresponding standard deviations of that ranges from 0.85-1.09. The mean scores are all lesser than the 2.5 criterion mean and implies a negative response. With a grand mean of 2.0 which is also lesser than the criterion mean, it implies that there is low level of awareness of heutagogy as a teaching and learning approach for $21^{\text {st }}$ century learners among lecturers in Adult and Non-Formal Education Departments in selected Universities in Nigeria.

\section{DISCUSSIONS OF FINDINGS}

Findings of the study show that lecturers that teach post graduate students in Adult and Non-Formal Education Departments in Nigeria Universities stillengage in pedagogical teaching and learning in their post graduate class. The lecturers determine how and when your student learn, their students still depend on them to give them notes when teaching, they still provide students with learning materials and also dictate notes in class, impose materials on student, making them to feel that the material they provided for them is the only source of knowledge, and so on. Palmer (2015) pointed out that a teacher is supposed to reflect on the changing society and that this change informs what teaching is to be but that teachers, lecturers inclusive in different categories of learning still assumes the central focus of the class, they take the active role of giving information to the students while the students assume passive role of receiving the information that the teachers teaches them.

Pedagogy creates dependency on the teacher as well as reducing initiate and creativity on the part of the students. Freire (2008) observed that usage of pedagogical assumptions by lecturer limits learner's experience and inadvertently subscribe to banking theory by using their authority as teachers to deposit knowledge and avoid anything aside from their role of depositing knowledge. furthermore, Micheletti (2010) stressed that student taught with pedagogical principle in practice believe that the teacher provides them with all of the learning needed because the lecturers are the best method of educational delivery. In the knowledge economy we are today there is need for urgent change in the pedagogies of teaching and learning at graduate level. In view of this, Christensen as cited in Lopez (2016, p.547) stated that " 21 st century teaching and learning methodologies are reflective of practices aimed at engaging students in cognitive learning, and the development of higher order thinking skills".

In the study, it was found out that lecturers in Adult and NonFormal Education Departments in selected Universities in Nigeria strongly agreed that there is need to change 
pedagogies in teaching and learning of adult education students mostly at the post graduate level to fit in with the challenges involve in the changes associated with the present knowledge economy because it is no longer a good approach for teaching post graduate students of the present knowledge economy that required student development of capability in which pedagogy is sort after. Pedagogy is a teacher centered kind of teaching which limits graduate student potential to show case their capabilities and thus required to be changed.

Chacko (2018) narrated the need to change pedagogy in teaching and learning at the post graduate level, he observed that at post graduate level, that "educators have recognised the need for a different approach to meet the learning needs and style of the newly qualified professionals (graduate students) who are highly autonomous and for whom pedagogical and even andragogical educational methods are no longer an answer to preparing the professionally to qualified the students to thriving in the workplace, That a more self-directed and self-determined approach is needed where the learner reflects on what is learned and how it is learned and where the educators teach the learners how to teach themselves, this is termed as Heutagogy building on humanistic theory of the 1950s" (p.279).

The study also found out that the level of awareness of heutagogy as a teaching and learning approach for $21^{\text {st }}$ century learners is low among lecturers in Adult and Non-Formal Education Departments in selected Universities in Nigeria. Low level of awareness of heutagogy is a challenge in the popularization of the approach, in view of this, Joshua (2017) suggested that teacher should embrace heutagogy and most important they need to be familiar with Wed 2.0 as a platform to help their students to become more independent not dependent associated with pedagogy. In support, Bakare (nd, p.2) asserted that in heutagogy, "the learner is expected to be independent and capable of organizing himself, and managing his own learning in a manner that will render him capable of applying the knowledge to effectively function in his chosen profession". Lecturers at post graduate level, are expected to acquaint themselves with heutagogy approach because it promotes knowledge sharing among student-student and student-lecturers, rather than knowledge hoarding as posited by pedagogy. For today knowledge economy that is surrounded with work place competences, educator or lecturers are supposed to exposed students to $21^{\text {st }}$ century knowledge economy competency requirements of intrapersonal, interpersonal and technology or ICT skills through the adoption of heutagogical approach.

\section{CONCLUSION}

The study concludes that due to the changing in the society which is also associated with changes in teaching and learning, heutagogy is an option for a change in pedagogies of teaching and learning. Students at all categories in Universities education, have different technology gadgets to source for information and be independent learners. These gadgets (phones, laptops) are readily available tools of easy switch from pedagogy to heutagogy. Producing knowledge based graduates for knowledge based industries and services requires exposure of learners to skill based teaching learning pattern, which heutagogy stand for.

\section{RECOMMENDATIONS}

Based on the findings, the following recommendations were made:

1. In other to help our post graduate student to develop capabilities in learning to suit the learning challenges pose by $21^{\text {st }}$ century societal need and also be change agents, lecturers should help the learners to embrace a learning culture of openness to exchange ideas with others.

2. Lecturers should avail themselves opportunities of training and re-training in new ways of teaching in the $21^{\text {st }}$ century to meet up with the competency demands (intra personal, inter personal and technology or information and communication technology skills) of present knowledge economy.

3. Government should provide enabling environment that will make lecturers to be abreast with innovations in teaching and learning for the $21^{\text {st }}$ century knowledge economy.

\section{REFERENCES}

[1] Agonács N, Matos JF. (2019) Heutagogy and self-determined learning: A review of the published literature on the application and implementation of the theory. Open Learn J Open Distance eLearn, 34:223-40.

[2] Anshu ST (2012). Principles of assessment in medical education. 1st ed. New Delhi: Jaypee; Portfolios in learning \& assessment. 173-9.

[3] Argyris C, Schon DA. (1992) Theory in practice: increasing professional effectiveness. Jossey-Bass Inc, San Francisco, California: Jossey-Bass.

[4] Bakare, T.V. (nd).The probability, prospect and efficacy of Heutagogy in distance learning for lifelong and continuing education in Nigeria. Assessed online from https://ir.unilag.edu.ng/bitstream/handle/123456789/7620/heut\%2 0current $\% 20$ pp1ii\%20corr22.pdf?isAllowed=y\&sequence $=1$.

[5] Blaschke LM. (2012) Heutagogy and lifelong learning: A review of heutagogical practice and self-determined learning. Int Rev Res Open Distance Learn 13, 56-71. Available from: http://www.irrodl.org/index.php/irrodl/.

[6] Blaschke, L.M. (2016). Strategies for implementing selfdetermined learning (heutagogy) within education: A comparison of three institutions (Australia, South Africa, and Israel). A Master Thesis submitted to Carl von Ossietzky Universität Oldenburg Program.

[7] Canning, N. (2010) Playing with heutagogy: exploring strategies to empower mature learners in higher education, Journal of Further and Higher Education, 34:1, 59-71, DOI: 10.1080/03098770903477102.

[8] Chacko TV. Emerging pedagogies for effective adult learning: From andragogy to heutagogy. Arch Med Health Sci [serial online] 2018 [cited 2021 Sep 27];6:278-83. Available from: https://www.amhsjournal.org/text.asp?2018/6/2/278/248661

[9] Cole, K. (2019). Pedagogy in education: More than a buzzword. Assessed online from https://www.schoology.com/blog/pedagogyeducation-more-buzzword.

[10] Freire, P. (2000). Pedagogy of the oppressed: 30th Anniversary Edition (Kindle Edition). Retrieved from Amazon.com. 
[11] Freire, P. (2008). The "banking" concept of education." Ways of reading. 8th ed. Bartholomae, David and Anthony Petrosky. Boston: Bedford- St. Martin's.

[12] Hase, S. and Kenyon, C. (2001) Moving from andragogy to heutagogy: Implications for VET, AVETRA, Adelaide, March. Available http://www.avetra.org.au/Conference_Archives/2001/abstracts.sht $\mathrm{ml}$

[13] Hase, S., \& Kenyon, C. (2000). From andragogy to heutagogy. Ultibase Articles, 5, 1-10.

[14] Kuit, J.A., \& Fell, A. (2010). Web 2.0 to pedagogy 2.0: A socialconstructivist approach to learning enhanced by technology. In Critical design and effective tools for e- learning in higher education: Theory into practice (pp. 310-325). United States: IGI Global.
[15] Léon-Henri, D.D.P (2021): What is the difference between didactics and pedagogy? Assessed online from https://reflectiveteachingjournal.com/

[16] Micheletti, G. (2010) Re-Envisioning Paulo Freire's "banking concept of education" Inquiries Journal, 2(2),1.

[17] The World Bank. (2003). Lifelong learning in the global knowledge economy: Challenges for developing countries. Washington, D.C.: The World Bank. Retrieved from http://siteresources.worldbank.org/INTLL/Resources/Lifelon g-Learning-in...

[18] Torres, C. A. (1994). Introduction. In M. Escobar, A. L. Fernandez, \& G. Guevara-Niebla; Paulo Freire on higher education: A dialogue at the National University of Mexico. Albany, NY: State University of New York Press, pp. 1-25. 